\title{
Organizational Performance, Firm Size and Chief Executive Officer's (CEO'S) Compensation for Firms Listed in Nairobi Securities Exchange, Kenya
}

\author{
Omamo Anne', Prof. Peter K'obonyo², Dr. Florence Muindi
}

\begin{abstract}
This study examined the link between organizational performance, firm size and CEO'S compensation of firms listed at the NSE. Past studies on the determinants of CEO'S compensation revealed a lack of consensus to the explanation of increases in CEO'S compensation. While most of the studies confirm linkages between organizational performance and CEO'S compensation, they measured organizational performance using financial indicators of performance, the current study investigates the relationship between organizational performance and CEO'S compensation but differs from the previous studies by expanding the measures of organizational performance to include the balanced scorecard measures of financial indicators, customer satisfaction, internal processes and learning and growth elements of performance. Additionally, the study sought to find out the moderating role of firm size on the relationship between organizational performance and CEO'S compensation. The theoretical foundation of this study was based on agency theory. A conceptual model and conceptual hypothesis were drawn from literature and provided directions for this study. The study's population constituted 60 firms listed at the NSE. Descriptive crossectional survey was adopted for this study. Primary data was collected to capture the opinion of board members on factors that determine levels of CEO'S compensation using semi structured questionnaire. Secondary data was gathered from the financial statements of the listed firms for 2015-2016financial periods. Descriptive statistics and stepwise regression were used to analyze and interpret the collected data. The study revealed that there was significant and positive relationship between organizational performance and CEO'S compensation. The study further found that firm size had a significant moderating effect on the relationship between organizational performance and CEO' Scompensation. The findings of this study are of benefit to board members of organizations in identifying the performance measures that are important to consider when making decisions on CEO'S compensation. Future researchers could consider expanding the scope of the study to include firms that are not listed at the NSE.
\end{abstract}

\section{Introduction}

As today's business environment become increasingly complex and global, they are faced with the challenges of managing continuous change, competition, cost constraints, increasing employee demands, legal requirements among others. Human Resource Management is seen as a major contributor in helping the organizations deal with these challenges by designing ways to effectively increase employee's productivity and commitment. To this end, one area of concern to human resource managers is the implementation of employee compensation programs that would satisfy employees' needs as well as contain the costs of labor for the firms (Bernardin, J. 2007). In trying to achieve this, firms have continuously seen the need to tie employees' levels of pay especially the executives to the levels of individual and organizational performance. As such decisions on designing the CEO'S compensation are crucial to an organization since they are responsible for the overall performance of the organization. One of the concerns in compensation management today is the variation in Chief Executive Officer's compensation. Literature indicates that CEO'S compensation levels vary from firm to firm and from industry to industry but there is no explanation for these variations. This study seeks to find out explanations to these variations by re- 
examining the influence of organizational performance, CEO'S power and firm size in the determination of CEO'S compensation levels.

According to Sonenshine et al, (2016) the debate on CEO'S compensation is largely centred on two view points. That is, whether the CEO'S earn their compensation through organizational performance and productivity or whether the CEO'S simply capture their compensation through extraction of rent due to weak board or poor governance. The first view proposing that CEO'S compensation ought to be associated to observable organizational performance measures like stock prices and earning so as to motivate the CEO'S to enhance organizational performance. On the other hand, the second view argues that CEO'S compensation is affected by the availability of rents and the bargaining power that the CEO'S have over the board of directors and shareholders. Equally, empirical studies have been able to establish that organizational size also influences CEO'S compensation and that larger organizations generally offer higher compensation to their CEO'S.

Organizational performance can be characterized as the firm's ability to create acceptable outcomes and actions (Reed et al, 2000). It comprises the actual output or results of an organization as measured against its intended outputs, goals or objectives. Upadhaya B. et al, (2014) propose that in recent years, many organizations have attempted to manage organizational performance using the balanced scorecard methodology where performance is tracked and measured in multiple dimensions such as financial performance, customer service, social responsibility and employee stewardship. Organizational performance from the stakeholder's perspective can be viewed as having met the expectations of a variety of stakeholder groups like employees, customers, suppliers, governments, local communities that have particular interest in the effects of the organization's activities. Organizational performance has been strongly associated to CEO'S performance (Epstein \& Roy 2005, Jensen and Murphy 1990, Wade Porac \& Pollock 1997 and Baptista, 2010). Firms vary in characteristics in terms of size, age, reputation, nature of business and ownership structures. These variations may explain the differences in their performance level and as such the CEO'S compensation. This study considered firm size as a moderating factor in the relationship between organizational performance and CEO'S compensation. This study focused on the firms listed at the NSE as its context and consists of 60 firms. It was expected that listed companies comply with the NSE and CMA regulations for them to continue selling at the browse. The Nairobi Securities Exchange has in place very strict and elaborate listing regime at the bourse, including disclosures, reporting obligations, financial requirements, records to be maintained, code of conduct, self regulations, submission of annual budget, and other corporate governance requirements. The listing requirements, though strict and at times viewed as inhibitive, are necessary to ensure that only the best managed companies find their way to the Nairobi Security Exchange. These requirements for the firms to be listed at the NSE provides a good ground to conduct the study and CEO's compensation due to easy access to relevant data on organizational performance aspects.

The study was anchored on the agency theory. Agency Theory is directed at the agency relationship, in which one party, the principal, delegates work to another, the agent, who performs that work. It attempts to describe this relationship using the metaphor of a contract (Jensen \& Meckling, 1976). The agency theory which proposes that the owners of a firm delegate authority to an agent, CEO, to make strategic decisions on their behalf. Agency theory suggests that the board will craft a compensation package that aligns the CEO'S goals with those of the shareholders (Elsenhardt, 1989). The next section provides definitions of the key study variables.

\section{Organizational Performance}

The definition of organizational performance as proposed by several writers is based upon the idea that an organization is a voluntary association of productive assets, including human, physical and capital resources, for the purposes of achieving a shared purposes or goal (Alchian \& Demsetz, 1972. Barney, 2002; Jensen \& Meckling, 1976; Simon, 1976). There are two main ways in which we can think of the theory of the firm and each has different implications for reporting organizational performance. These are the shareholder theory and stakeholder theory (Owen, 2006, Brown and Fraser, 2006). In the 1980's the firm was viewed as belonging to shareholders and so the shareholder theory, which uses shareholder return to measure overall firm performance dominated organizational performance measurement system, (Porter, 1980). However since the early 1990's a more stakeholder based view gradually began to prevail. This perspective views the 
firm as having responsibilities to a wider set of groups than simply shareholders. Other stakeholders include employees, customers, suppliers, governments, industry bodies, local communities and so forth (Reich, 1998, Post et.al, 2002, Brown and Fraser, 2006). It assesses organizational performance against the expectations of a variety of stakeholder groups that have particular interests in the effects of the organization's activities.

As observed by Tariq (2010) organizational performance can be measured using return of equity (ROE) which is derived by dividing net income and firms total equity. ROE is used to provide the organizations level of efficiency in making profits for every unit of equity utilized. He further proposes that organizational performance is influenced by several factors including general economic conditions, inflation, the kind of industry the organization operates in, competition, market condition and so on.

Wade et. al. (1997) propose that the performance of public held companies can be broken down in three components namely; accounting returns and profitability, stock market returns and 'beta' which measures the volatility of a company's stock price relative to broad market indicators. They further argue that high accounting returns like return on equity, imply that management has been successful in balancing revenues and costs and making good use of organizational assets to create value. Market returns represent the collective opinion of investors on the organizational abilities to generate wealth. Such that higher shareholder returns legitimize management. Company 'beta' is also a measure of organizational performance (Brealey and Meyers 1988). It is an index of volatility of a company's stock price in relation to broad market indicators. Such that, a high beta whether in positive or negative direction implies that changes in the organization's stock price are much greater than changes in the market as a whole. Epstein and Roy (2005) argue that in the past years, researchers have suggested a number of management systems to hasten the development of critical measures that can guide long term corporate decision (Eccles, 1991; Ittner and Larcker, 1998; Kaplan and Norton, 2000). These managerial systems mainly rely on the identification of organizational strategic objectives, the key performance, indicators and drivers and a wider set of both financial and non-financial measures of performance.

Growing importance has been given by academicians and consultants to the balanced scorecard approach as a useful tool for the development of strategic management and performance measurement system. One dominant approach which has been universally accepted to measure organizational performance is the Balance Scorecard (BSC) system by Kaplan and Norton (1992) which is based on the stakeholder theory. The BSC incorporates financial, customer/market, short-term efficiency and long-term learning and development factors. Mooraj et.al, (1999) argues that although the BSC's are common, they are primarily a tool for measuring external and internal economic value. This study therefore adopts the BSC approach of organizational performance measurement.

\section{Firm Size}

Previous researchers have identified firm's characteristics that influence the firm's ability to perform. The identified characteristics include firm size, age, reputation and legitimacy (Ferreira et al, 2008). Golan et al, (2003) propose that firm's resources and objectives summarized as firm characteristics influence performance of the organizations. The current study focuses on firm size as a measure of firm characteristic. In most theoretical and empirical studies where firm size is used, it is described in form of the number of employees, total assets, sales or market capitalization (Trigueiros, 2000). Baptista (2010) proposes that size can be measured using sales or market capitalization. He further observes that sales is the most commonly used measure for firm size. Kimberly, (1976) noted that the definition of firm size seems rather easy, a number of differing operationalization of firm size do exist. He proposes that firm size can be defined in terms of the physical capacity of a firm, the number of employees available in the firm, the input and output of an organization or the resources available to the firm. He asserts that the number of employees has been proved to be the best indicator of organizational size. Beer, (1964) defined organizational size as the number of employees that exist in a firm. SFirm size has been shown to have a significant, positive effect on CEO'S compensation (Finkelstein and Hambrick, 1989). The best CEO'S manage the largest firms, as this maximizes their impact and economic efficiency (Gabaix and Landier, 2008). They predict that CEO'S equilibrium pay is increasing with both size of the firm and the size of the average firm in the economy. 


\section{CEO'S Compensation}

Bernardin (2007) defines compensation as all forms of financial returns and tangible benefits that employees receive as part of an employment relationship. Executive pay is financial compensation received by senior managers of a firm. It is typically a mixture of salary, bonuses, shares and or call options on the company stock, benefits and perquisites, ideally configured to take into account government regulations, tax law, the desires of an organization and the executive, and performance (Elling 2002). The mixing of the different components of pay into a complex compensation package for executives allows the shortcoming of one component to be offset by the strength of another. Cash bonuses focus executives on the immediate success of the firm by paying them for reaching short-term goals. This counters the shortcoming of restricted stock that base awards on the long run outcomes and does not pay rewards for short-term production. To reduce the problem of the company stock price moving based on market forces and not that of the executive's movement of a market index of stocks (Sigler, 2011). Over the past three decades, executive pay has risen dramatically relative to that of an average worker's wage in the United States, The Guardian, 2005, and to a lesser extent in some other countries. Observers differ as to whether this rise is a natural and beneficial result of competition for scarce business talent that can add greatly to stakeholder value in large companies or a social harmful phenomenon brought about by social and political changes that have given executives greater control over their own pay, (Bebchuk and Fried 2004). Executive pay is an important part of corporate governance and is often determined by a company's board of directors.

A major challenge that scholars encounter in trying to understand the factors that determine CEO'S compensation is the various components that constitute the total remuneration of CEO'S compensation package. Besides the terms used by researchers, industry and countries are not consistent and tend to cause confusion. A case to mention is that performance share plan is a commonly used term in the United Kingdom as opposed to long term incentive plan (LTIP) in the US which refers to the same type of plan. Adopting Farmer (2008) definitions; a basic pay could be provided to CEO'S on a monthly basis and is a constant amount with no risk of non-payment. The CEO'S are also offered a bonus which is at risk of nonpayment since it is dependent of organizational performance. This highest bonus is paid when performance goes beyond the upper threshold yet no bonus will be paid for performance below a lower threshold.

CEO'S are eligible to receive grants of share options within the rules of long term incentive plans. The value of the share option will move in the same direction with the company share price hence they are also at a risk of decreasing in value just like the bonus. Most CEO'S are also entitled to benefits such as club membership, driver, housing allowance, security, education, holidays, medical covers among others. Most organizations also provide the CEO'S with a retirement plan. Going by disclosures ont eh annual reports of firms listed at the NSE, CEO'S compensation largely consists of salaries, allowances, cash bonuses and fees for services as directors (Aduda, 2011). Sigler (2011) writing on the components of CEO'S compensation for American firms, noted that the first component of CEO'S compensation is base salary which comprises $11.2 \%$ of their compensation. Going by the study by Economic Research Institute in 2010, CEO'S base salaries are determined by the opinion of compensation committee who largely consist of the members of the board of directors.

Secondly, CEO'S compensation include incentive plans consisting of cash bonuses which are paid in lumpsum at the end of the financial year as a way of motivating performance of the CEO. Bonuses act as incentives which are paid to the CEO'S upon attaining previously set goals. Bonuses are linked to accounting measures and are highly associated to the CEO'S specific areas of responsibility. They are aimed at motivating the CEO to pay more attention on the company's key objectives of increasing shareholder value and in turn their own wealth. Bonuses may be provided in association to the achievement of short-term, intermediate term, or even long term goals of an organization. A third component of CEO'S compensation could be seen as executive stock options which also act as an incentive to the CEO'S. The stock options could be provided in various forms including qualified incentive stock options and non qualified stock options which are used by many organizations as forms of equity compensation for CEO'S to drive them towards working in the best interest of shareholders. The qualified stock options provide a tax benefit but they equally have complicated tax consequences. Non qualified stock options have a draw back to the CEO'S since taxable income is usually reported at the time when the non-qualified options are exercised without the consideration of whether the stocks have been sold or not. Qualified stock options 
mitigate this disadvantage since they do not report any income at the time they are exercised unless the stock is sold. Executive stock options tend to reduce greater risk aversion by providing the CEO'S an incentive to increase organizational risk by allowing risky but profitable projects as opposed to avoiding them.

A fourth form of CEO'S compensation is the restricted stock ownership of an organization which merges the interest of shareholders and the CEO'S. Restricted stock limits the shares that a CEO can own. A common restriction is the imposition of the time period that has to elapse or for the achievement of particular goals before the CEO can cash in the stock. A fifth compensation component for CEO'S is a golden parachute that consists of lucrative benefits that CEO'S are offered in the event that the organization is taken over by another firm causing the CEO to lose their job. Specifically, the golden parachute items include: stock options, severance pay and bonuses. The sixth and last component of CEO'S compensation constitutes benefits that go to the CEO and includes retirement plans, life insurance, medical cover, car allowances, club membership, travel re-imbursements, paid holidays and vacations. The table below provides a summary of the key components of CEO'S compensation and their alternative names.

\section{Table 1: Components of CEO'S compensation}

\begin{tabular}{|c|c|}
\hline Compensation component & Alternative terminology \\
\hline Basic pay & $\begin{array}{l}\text { 1. Annual salary } \\
\text { 2. Base pay }\end{array}$ \\
\hline Short-term incentive (ST) & $\begin{array}{l}\text { 1. Annual performance bonus } \\
\text { 2. Bonus }\end{array}$ \\
\hline Deferred cash bonus & 1. Deferred bonus \\
\hline Executive share option (ESO) & $\begin{array}{ll}\text { 1. } & \text { Share options } \\
\text { 2. } & \text { Stock options } \\
\text { 3. } & \text { Time-vested options } \\
\text { 4. } & \text { Performance options } \\
\end{array}$ \\
\hline Restricted stock & $\begin{array}{l}\text { 1. } \text { Time-vested restricted stock } \\
\text { 2. Performance share plan (PSP) } \\
\text { 3. } \text { Long-term incentive plan (LTIP) }\end{array}$ \\
\hline All employee share plan & $\begin{array}{l}\text { 1. Save as you earn (SAYE) } \\
\text { 2. Share save scheme }\end{array}$ \\
\hline Benefits in kind & $\begin{array}{ll}\text { 1. } & \text { Perquisites } \\
\text { 2. } & \text { Benefits } \\
\end{array}$ \\
\hline Retirement plan & 1. Pension \\
\hline
\end{tabular}

Source: Farmer (2008)

\section{Literature Review}

According to Ozkan (2011), the compensation package of CEO'S has been viewed as an important factor in resolving the conflict of interest between executives and shareholders of organizations. Organizations today have come to the recognition that CEO'S compensation could be a useful tool in motivating CEO'S to act in the best interest of the organizations. The rapid increase in CEO's compensations has provoked renewed interest in understanding the factors that determine CEO's compensation. At the centre of the debate are arguments concerning whether the compensation increases are earned by the CEO's due to good performance and productivity or whether it is the CEO who have power to drive their pay upwards by extracting rents from a weak board (Sonenshine et al, 2016).

The compensation of CEO'S is a matter of considerable interest to both academics and practitioners (Buigut $\mathrm{K}$, et al, 2014). Gabaix et al (2013) argue that CEO'S compensation has remained at the centre-stage of academic and policy debates yet there seems to be lack of consensus regarding the origins of the large rise in CEO'S compensation. Organizational and strategy researchers have analyzed a wide variety of determinants of CEO compensation reaching desperate and sometimes contradictory or mixed conclusion (Elhagrasey \& Harrison, 1999). According to Babchuck and Fried (2004) the increase in CEO'S compensation can be explained by the ability of the CEO'S to extract rents for shareholders by capturing their board or appointing compensation consultants that cater for their interest. However, Hermalin (2005) opposes this previous view and instead argues that the increase in CEO pay reflects tighter corporate governance. CEO'S pays rise in 
order to compensate them for the greater risk of being fired. Other scholars argue that the function of CEO'S has changed over time and today's CEO'S are now more often poached from outside firms than before (Murphy and Zabojnik, 2004; Frydman, 2005). Frydman and Jenter, (2015) argue that there has been a rapid increase in CEO'S compensation over the last 30 years and this has led to debate on the nature of the process of determining compensation levels of CEO'S. They further propose that many scholars are of the opinion that the high levels of CEO'S pay can be explained by the high power that CEO'S have in determining their own pay levels.

\section{Organizational Performance and CEO'S Compensation}

Firm performance is argued to be the major determinant of CEO compensation and that on the basis of literature; firms should compensate their CEO'S depending on how much they bring to the firm. Previous studies by Buigut, et al, (2014); Chalmer \& colleagues, (2006); Kubo, (2001); Fenkelstein, Hambrick, (1989), indicate that firm performance is positively related to CEO'S compensation. Ozkan (2007) suggests that in the UK, organizational performance has a positive relationship with CEO's compensation and this applies more with the cash forms of compensation. While other studies like, Tarus, et al, (2014); Flrming \& Stellios, (2002); Izan et al, (1998); Jensent \& Murphy, (1990), show a weak or negative relationship between firm performance and CEO'S pay. A number of firm specific characteristics like size can be thought of as influencing executive compensations. Brick et al, (2005) found a strong but negative relationship between organizational performance and CEO's compensation. Shah and Javed, (2009) observed that organizational performance is considered to be perhaps the most significant determining factor of CEO'S compensation. Studies by Hijazi \& Bhatti, (2007); Tosi et al, (2000); Ramaswamy et al, (2000), found out that firm size is a statistically significant variable in determining CEO'S compensation when measured in terms of total assets. But others like Lambert \& colleagues (1991) and Boyd, (1994), found weaker relationship between size and CEO'S compensation when measured by sales. Historically, literature on CEO'S compensation provides an emphasis that CEO'S compensation should be linked to organizational performance. Some academic studies suggest CEO'S compensation to be better predicted by profit. According to Fenkenlstein \& Hambrick, (1989) and Deckop (1988), organizational profitability is strongly related to CEO'S compensation while return on equity is unrelated to CEO'S salary but positively associated to bonuses that CEO'S receive. However, some studies record contradicting results on the relationship between organizational performance and CEO'S compensation. There is a weak relationship between CEO'S compensation and stockholders wealth (Jensen \& Murphy, 1990). Fleming \& Stellions, (2002) also found no relationship between organizational performance and CEO'S compensation. Chalmers \& Colleagues (2006) revealed that return on asset was strongly related to all components of CEO'S compensation and that CEO'S bonuses are related to annual stock market returns.

Farmer (2008) argues that literature on CEO'S compensation has considerably increased over the last 60 years and covers an array of disciplines including accounting, economics, law and organizational strategy. Accountants like Healy (1985) in his studies considered the link between accounting based compensation incentives and manipulation of earnings. Baimen and Verrechchia (1995) also accountant, explored the relative effectiveness of accounting-based compensation and market-based performance measures. Jensen and Murphy (1990) who were financial economists, focused their studies on the relationship between CEO'S compensation and organizational performance. They also studied the influence investment decision, capital structure, dividend policies mergers and diversification on CEO'S compensation. According to Wade et.al; (1997) the amount of compensation a CEO receives is on one-half of the current debate on payfor-performance. The other half is about the actual performance or organizations. Poor organizational performance sparks scrutiny of investors who are seeking to place the blame of poor performance on management. On the other hand when organizations report high performance justification for higher CEO compensation is eased by relaxing legitimacy threats.

The principal-agent problem has partially resolved using CEO'S compensation so as to align the CEO'S interest with the interest of sharehlders (Jensen \& Meckling, 1976). Holmstrom (1982) argue that in principle, the compensation of CEO'S should be pegged on the most informative indicators in terms of whether the CEO has taken action that maximize shareholder's value. Since in reality the shareholders are not likely to understand or know the particular actions that maximize value, the incentive forms of compensation offered to CEO'S should be those that help the principals achieve their ultimate objective of 
shareholder value maximization. Through the effective designing and provision of ownership stake to a firm, compensation offered to CEO'S that are linked to equity, creates a motivating force for the CEO'S to take actions that benefit shareholders. Optimal contract helps balance the provision of incentives to CEO'S against exposing risk averse CEO'S to much volatility in their compensation.

Previous literature generally shows a strong relationship between organizational performance and CEO'S compensation where firm performance is measured by return on asset (ROA) and return on equity (ROE) (Finkelstein Hambrick, 1989 and Kobo, 2001). They argue that the profitability of firms is a better determination of CEO'S compensation. According to Guest (2009) there is a positive relationship between board size and CEO's compensation. Board members are an important source on internal control mechanism in setting CEO's compensation. They also have the responsibility in deciding the succession of the CEO and future projects of the organization (Rahaja, 2005). Core et al, (1999) argue that CEO's compensation is influenced by a number of factors including firm performance, firm size, complexity of firm, growth opportunities and board structure. Concerning the pay-performance relation, there is wide evidence for a strong relation in the US. Jensen and Murphy (1990) found a positive and significant relation between cash compensation and firm performance measured by shareholder wealth. In addition, Joskow and Rose (1994) suggest a robust relation firm performance measured by both market-based and accounting measure and total compensation.

Jensen \& Meckling (1976) observed that it is important to align organizational performance with CEO'S compensation. They demonstrated that a CEO with less than sole ownership of the organization usually is motivated to take actions that may decrease organizational value. When designing CEO'S compensation structure, organizations will provide long-term executive stock options in an attempt to motivate the CEO to act as an owner would do. Leonard (1990) asserts that when CEO'S are offered long term incentive plans, there will be an increase in organizations return on equity as opposed to those firms that do not offer longterm incentive plans. Jensen and Murphy (2010) also proposed that the compensation of CEO'S in most public companies is highly associated with organizational performance.

Rose and Joskow, (1994) found that past performance influences not only cash compensation, but also total compensation. In line with Jensen and Murphy, they found that the lagged performance effect decays considerably over two to three years. They used not only market-based measures of performance, but also accounting measures. For stock return, they find that 1-year lagged return has at the least the same impact on current compensation than current return, but that further lags have a small effect on compensation. For accounting returns, they find that the returns effect compensation decays almost proportionally over time. Other studies show no relationship between organization performance and CEO'S compensation (Fleming \& Stellio, 2002, Izan et al, 1998, Defina et.al., 1994). Tosi \& Collegues (2002) also found a week relationship between CEO'S compensation and firm performance. Chalmers \& Colleagues (2006) show that ROA is positively associated with all compensation components except shares.

Aduda, (2011) conducted a study on the relationship between executive compensation and firm performance on commercial banks listed at Nairobi Securities Exchange and the results indicated that accounting measures of performance are not key considerations in determining executive compensation among the banks in Kenya and that instead size is a key criterion in determining executive compensation. These two studies only focused on the directly compensation in specific industries. The current study expands performance measures to include operational and market based measures among all the firms listed in Nairobi Securities Exchange which has a representation of companies in various industries. Wade, Porac, and Pollock, (1997), conducted a study on how the compensation committees of a sample of U.S corporations from the S and P 500 justify their compensation practices to shareholders. They found that when companies have more concentrated and active outside owners, they are much more likely to justify their compensation practices by citing the role of compensation consultants as advisors in the compensationsetting process. They are also more likely to discuss the alignment of managerial and shareholder interests and to downplay a company's accounting returns. Companies that pay their CEO'S large base salaries are also more likely to cite the role of consultants and for those with dispersed ownership, to discuss shareholder alignment. High accounting returns lead companies to emphasize accounting performance in their compensation justification and to downplay market returns. Another study by Epstein and Roy, (2005) on evaluating and monitoring CEO'S performance found that although there are a growing number of 
companies using non-financial metrics to evaluate CEO'S performance, their results confirmed that CEO'S are primarily evaluated on financial criteria, indicating a narrow definition of corporate performance. In the current study organizational performance is considered as a reflection of CEO'S performance and is measured in terms of SBSC measures.

Most of studies on executive compensation have been carried out in the context of American and European organization. Khana and Palepu, (1997), have pointed out that the significant differences in the institutional context in which firms in emerging markets like Kenya operate. In Kenya the effect of economic liberisation along with a wide range of changes in the market for managerial talent has resulted in significant changes in the compensation policies adopted by firms. The studies reviewed above show that there are relationships between organizational performance, CEO'S power, firm size and CEO'S compensation. A majority of the studies focused on the relation organizational performance as the key determinant of CEO'S compensation with most of them finding positive relationships and a few others revealing weak or even negative associations. Besides the studies measured firm performance largely by accounting indices.

\section{Organizational Performance, Firm Size and CEO'S Compensation}

Past academic works generally show a strong relationship between firm size and CEO'S compensation. CEO'S compensation is more closely related to organizational size when size is measured by sales and it is less related to profits (McGuire \& Colleagues, 1962). This kind of relationship indicates that increases in sales will lead to CEO'S being paid more than increases in profits. As such the CEO will exert more effort towards sales maximization rather than profit maximization. Hijazi and Bhatti (2007) also found that organization size affects the complexity of jobs and organization's ability to pay which in turn influences the decisions of CEO'S compensation. However, the foregoing arguments were contradicted by Lewellen and Huntsman (1970) whose study results reveal a positive relationship between CEO'S compensation and organizational profits rather than sales levels. This he justified by arguing that business organizations ultimate purpose for shareholders and executives is to maximize profits of the organization to deliver a return to the shareholders. This implies that CEO'S who contribute efficiently to profit maximization would be rewarded with high compensation. Other studies show that larger organizations will require CEO'S who have higher quality skills, qualifications and diverse characteristics and should therefore be compensated accordingly (Chalmers et.al, 2006).

Frydman and Jenter, (2015) argue that an increasing literature links increase in CEO'S compensation to increase in firm sizes and scale effects. Larger firms value more talented CEO'S and are willing to offer higher levels of compensations so as to match the efficient labour market of competent CEO'S. This is supported by the fact that small improvements in CEO'S talents may translate to high increments in firm value and in turn lead to increase in compensation due to the large scale of operations that the CEO'S is in control of (Himmelberg and Hubbard, 2000). Gabaix and Landier (2003) while using the assumptions on the distribution of CEO'S talent, they show that CEO'S compensation should move hand in hand with changes in firm size. As such they argue that the increase in CEO'S compensation witnessed between 1980 and 2003 were fully attributed to the increase in market capitalization over the same period.

According to Elhagrasey et.al, (1999), organizational performance and firm size are the most consistent determinants of CEO'S compensation found in previous research. Large firms provide higher CEO compensation and justify it by greater responsibility that the CEO has, greater complexity in the CEO'S job, larger scale of operations in the firm and equivalently higher compensation offered to CEO'S in other large competing firms. Equally, more profitable firms offer their CEO'S higher compensation and they justify it as a reward for the CEO'S strong managerial performance. When firms post higher profits, the CEO'S task to legitimize their compensation increament is rather straight forward. However, when organizations are smaller or organizational performance is poorer it would be more difficult for the CEO.

A large body of empirical evidence associates increases in CEO'S compensation to increase in firm size (Kostiuk, 1989 \& Murphy 1985). The elasticity of CEO'S compensation to firm size cold be estimated at 0.25 implying that $10 \%$ increase in firm size will lead to $2.5 \%$ rise in CEO'S compensation. The direction of this kind of relationship is justified by the fact that CEO'S or larger organizations need to be offered compensation that are in line with the greater economic effects of their actions (Gayle \& Miller 2009). Growth in literature continues to provide evidence for the association of CEO'S compensation to firm size. 
According to Rosen (1992) the productivity expectations for a CEO grows with increase in firm size due to the reason that the CEO'S of large firms make decisions to utilize a larger pool of employees and other resources. Larger firms will look out for more talented CEO'S in the already competitive labour market and will therefore compensate the CEO'S based on their productivity, firm size and ability. Tosi et al, (2001) with this line of thought that the reason for the strong relationship between CEO'S compensation and firm size is due to greater organizational complexity, more stratification and larger human capital that exist in larger firms.

According to Frydman and Jenter (2005) there are theories which propose that changes in firm characteristics like technologies, products, market size also act as a major factor that influences CEO'S effort, talent and organizational value and this in turn affects the level of CEO'S compensation. Like an increase in firm size leads to increase in CEO'S effort, and as a result an increase in CEO'S incentive compensation (Himmerlberg \& Hubbard 2000; Baker \& Hall, 2004). In opposition to the managerial power approach to the explanation of CEO'S compensation, Frydman \& Jenter (2005) observe that there is growth in literature at associate CEO'S compensation increase to increased demand for CEO'S scarce talent. They further argue that increase in CEO'S compensation is attributed to increase in firm size which expands the scale of operations Such that highly talented CEO'S are of more value to large firms and so larger firms should be ready to offer higher compensation levels to their CEO'S to much the capabilities of the CEO and win the war for talent in a competitive market (Rosen, 1982). Gabaix and Landier (2008) and Tervion (2008) concur with this line of thought by proposing that CEO'S talent has a multiplicative effect on organizational performance. CEO'S compensation should move hand in hand with changes in firm size. They use this to explain the six fold increase in CEO'S average compensation between 1980 and 2003 which also recorded a similar increase in average market capitalization. According to Gayle and Miller (2009), moral hazard problems are usually higher in larger organizations leading to higher CEO incentives as the organization grow in size.

A number of earlier studies on CEO'S compensation have included firm size as a variable of interest. The basis assumption behind this is that larger firms will have the ability to compensate the CEO highly because of their inferred large size in business resulting in greater revenues and profits (Core et.al; 1999; Murphy 1999; Ramaswamy et.al; 2000; Talmor and Wallace, 2001; Ghosh 2003). Core et.al; 1999; Talmor and Wallace 2001; Gohsh 2003) found that firm size is statistically significant in influencing CEO'S compensation.

Literature and academic works show that there is a strong relationship between firm size and CEO'S compensation. Roberts, (1959) and McGuire, (1962) in their studies found that CEO'S compensation was more closely related to size of the firm when measured by sales and less related to profits. This implies that when sales increase, CEO'S are likely to be paid more than with any increase in profits. Hijazi and Bhatti, (2007) found that company size is closely related to job complexity and employer's ability to pay in determining executive pay. Later studies show that firm size is considered to be the strongest determinant of CEO'S compensation when measured in terms of total assets (Ciscel, 1994; Finkelstein and Hambrick, 1989; Chalmers et al, 2006). CEO'S who have higher quality skills, qualifications and diverse characteristics are required for larger firms and as such are paid accordingly.

Lambert et al, (1991) found a weaker relationship between firm size and executive compensation as opposed to suggestions by previous researches and argued that changes in organizational size do not necessarily affect CEO'S compensation. Boyd, (1994) also found a weak relationship between CEO compensation and firm size measured by $\log$ on net sales. Still other studies measure the firm size in terms of sales and found a strong relationship with CEO'S compensation (Deckop, 1988; Jones 1996; Magnan et al, 1995). But the overall differing results are disturbing. Firm size and profitability are the determinants of CEO compensation found most consistently in previous research. Higher CEO compensation in larger firms can be justified by greater CEO responsibility, a larger scale of operations, greater complexity in the CEO'S job and high compensation for CEO'S in other large firms. Higher compensation in more profitable firms can be justified as a reward for strong managerial performance. In large, profitable firms, the CEO'S task in legitimizing high compensation is relatively straightforward (Elhagrasey, et al, 1999)

\section{Theoretical underpinning}


To shed new light on the ongoing controversy on CEO compensation, the study was grounded on agency theory. According to Abed et al. (2004), it is not only in practice but also in theory that the debate on the determinants of CEO'S compensation is far ending. However, although various theories have been proposed to explain CEO'S compensation, this are of study is till largely dominated by the agency theory. The domain of the agency theory is relationships that mirror the basic agency structure of a principal and an agent who are engaged in co-operative behavior, but have different goals and differing attitudes towards risk (Eisenhardt, K., (1989). The theory is concerned with resolving two problems that can occur in an agency relationship. The first problem that may arise is when the desires or goals of the principal and agent conflict and secondly, the difficulty for the principal to verify what the agent is actually doing. Thus the principal cannot verify that the agent has behaved appropriately and there is also a problem of risk sharing when the two have different attitudes towards risk. Agency theory evolved from risk sharing research in economics. The unit of analysis is the relationship between a principal and agent, and the theory addresses causes and consequences of goal divergence between the two parties. Consequently, agency theory is a particularly useful framework for addressing CEO/board relations.

Agency theory proposes that the owners of a firm delegate authority to make strategic decisions on their behalf to an agent: the CEO. Agency theory highlights the existence of an agency problem: a CEO and the firm's shareholders often have differing interest such that the CEO may make moves that are in her best interests even if they hurt the firm (Jensen \& Mackling 1976). The shareholders' main watchdog is the board, whose job includes monitoring the CEO and managing the CEO'S compensation package. Ideally, the board will craft a compensation package that aligns the CEO'S goals with those of the shareholders (Elsenhardt, 1989). Many boards for example emphasize stock options and other forms of contingent compensation. By drawing a connection between the CEO'S pay and firm performance, the board strives to motivate the $\mathrm{CEO}$ to pursue courses of action that maximize shareholder returns. In crafting a compensation package, the board should consider not only the overall value but also the mix of the pay elements in the compensation package. Rather than determining how much to pay executives, the central legitimizing issue in the agency approach is how to pay them (Barkema, Geroski, and Schwalbach, 1997; Jensen and Murphy, 1990). Pay levels are in this approach mainly assumed to be based upon the market value of executives' services. As pay is seen as a consequence of agency problems, the question how to pay the executive is the main issue addressed in these theories. Agency problems exist in any situation where one party entrusts responsibility of tasks to another party.

It is expected that CEOs will work in the interest of the organizational shareholders. But there are chances that the CEO may choose to work on his own interest and not in the interest of the shareholders. This can be resolved by aligning the interest of the CEO with that of the shareholders by linking CEO's compensation to performance of the firm (Khanna, 2016). Aligning the interest of the agent CEOs with the interest of the principal's shareholders is a way out of the principal-agent problem using firm performance as a determinant of CEO's compensation (Gunasekaragea and Wilkinson, 2002). Core et al, (2003) view the determination of CEO's compensation as a principal agent relationship. He argues that CEO's compensation contracts are designed by boards in such a way as to provide incentives to the CEOs to work hard and maximize shareholder value. Berle and Means, (1932) argue that the principal agent problem that exists between firm executives and their shareholders has been of an area of interest since the separation of corporate ownership from corporate ownership from corporate control by company boards at the turn of $20^{\text {th }}$ century. They further argue that when executives have their self interest and shareholders do not have the ability to perfectly monitor the executive's behavior, the executives will be inclined to fulfill their needs as opposed to increasing shareholder value. Empirical evidence on consumption of executive perquite, building or empire and preference for a quite life imply that the principal agent problem has a high potential of threatening the value of firms (Jensen and Meckling), 1976; Jensen 1986; Morck et. al. 1990; and Bertrand and Mullainathan, 2003.

The agency problem can be partially resolved using executive compensation by aligning the needs of a manager with those of shareholders (Jensen and Meckling, 1976). Organizations hope that by offering CEO'S an ownership stake in their firms through equity-linked compensation, the CEO'S would be motivated to act in the benefit of the shareholders. 


\section{Conceptual Framework}

The conceptual model of this study considered how Organizational performance, CEO'S power and firm size affect the determination of CEO'S compensation. First it showed that organizational performance is the main factor that firms considers in making CEO'S compensation decision. Organizational performance is measured on the basis of balanced score card elements including financial measures, customer satisfaction, internal processes success, learning and growth strategies. It indicates that the relationship between organizational performance and CEO'S compensation is moderated and firm size. It advances an argument that in as much as organizational performance is a key consideration for determining CEO'S compensation. It further proposes a case for firm size moderating the relationship between organizational performance and CEO'S compensation. The firm size may either strengthen or weaken the relationship between organizational performance and CEO'S compensation. Firm size is a factor that has been considered to influence organizational performance and as such CEO'S compensation.

\section{Figure 1: Conceptual Framework}

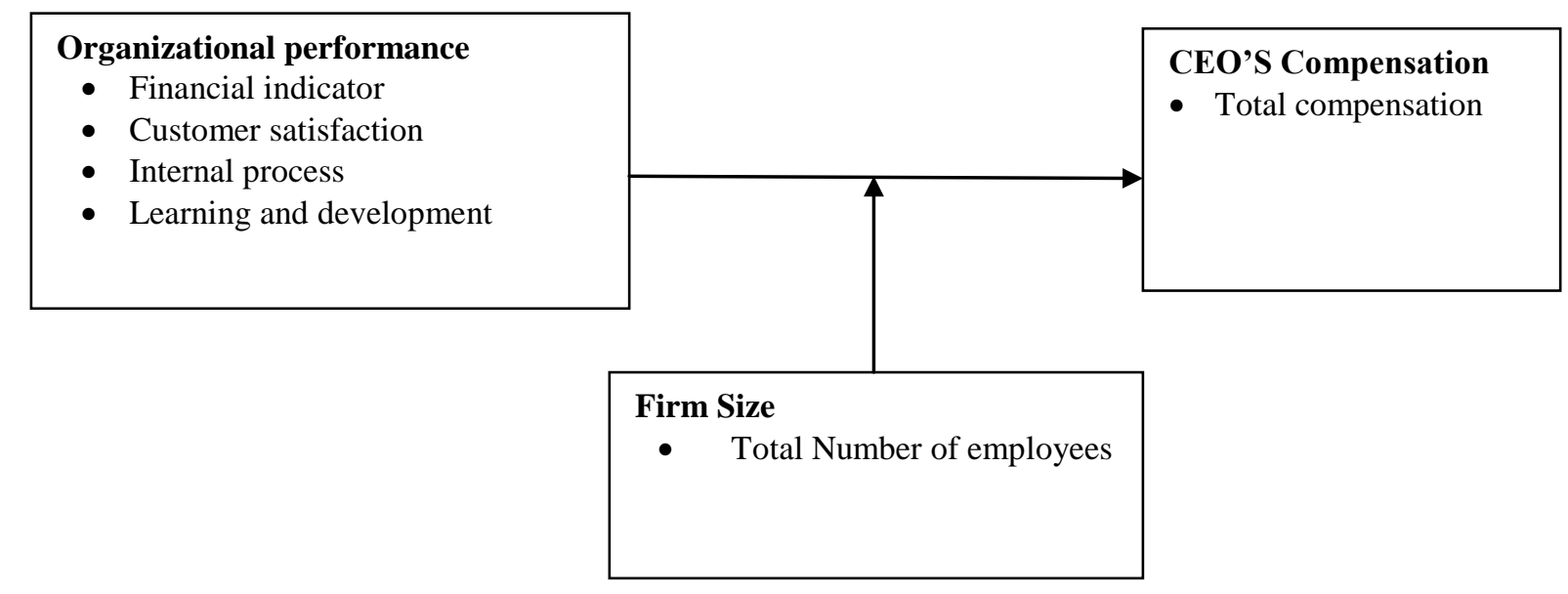

\section{Research Methodology \\ Research Design}

The current study adopted the positivist approach as the basis for the methodology and procedures used in this study. This approach allowed use of quantitative data to test the research hypotheses drawn from the theoretical framework. The research design that was adopted was descriptive cross-sectional design, which involved identification and description of phenomena or characteristics associated with a subject population (who, what, when, where, and how of a topic). It allowed estimates of the proportions of a population that has these characteristics. The approach allowed discovery of associations among different variables is possible, in order to determine if the variables are independent (or unrelated) and if they are not, then to determine the strength or magnitude of the relationship. Questions are carefully chosen, sequenced and precisely asked of each participant. Cross-sectional studies are carried out once and represent snapshot at one point in time (Cooper and Schindler, 2008).

A descriptive cross-sectional design enabled the researcher to establish any relationships between and among organizational performance, firm size and CEO'S compensation of firms listed in NSE. Financial data was collected for the period 2016/2017. The design was chosen considering the type of data and the analysis that is carried out.

\section{Data Collection and Analysis}

The relevant population for the study comprised all companies listed at the Nairobi Securities Exchange (NSE). According to the Nairobi Securities Exchange Handbook 2016, the total number of listed companies at the browse was 60. This study was therefore a census survey of all listed companies. The study used primary and secondary data to test the hypotheses. The primary data on organizational performance and CEO'S compensation collected using a structured questionnaire. The questionnaire was researcheradministered to the firms' board of directors with assistance from the company secretaries who are also the 
secretaries to the board. The questionnaire gathered data on the Organizational performance, CEO'S compensation. The questionnaire was on Likert-type statements anchored on five-point rating scale ranging from none (1) to very high (5). This approach was also applied in related studies like Kidombo (2007), Ongore (2008) and Chang (2010). Secondary data on firm size (total number of employees).

Questionnaires were administered to all the 60 firms. However, responses were only obtained from only 40 firms. This represents a 66.67 percent response rate which is considered representative and satisfactory to draw conclusions for the study. Although the intention was to randomly collect data from four directors in each firm, in reality, this was not possible. On average, responses were received from at least two directors in each firm. However, due to the sensitive nature of this study, and based on the promise of confidentiality, the names of the companies from which data was collected are not disclosed.

Data was analyzed using descriptive statistics in order to describe the main characteristics of the variables of interest in the study. Mean scores and standard deviations were computed for Likert type questions and results presented in form of tables. Pearson's Product Moment Correlation (r) analysis was used to assess the strength and direction of the relationships between study variables. Coefficient of determination $\left(\mathrm{R}^{2}\right)$ was used to measure the amount of variation in the CEO'S compensation due to the predictor variables. The analytical techniques used to test hypotheses are presented in table 2.

\section{Number of Employees}

The study sought to find out the number of employees in the firms listed at the NSE. This was intended to be used as a measure of firm size. The results indicated an average response of 3.625. This implies that the firms listed at the NSE had 500 to 2000 employees.

\section{Adjustment of CEO'S compensation}

The study sought to investigate the percentage adjustment of the CEO'S pay between 2015 and 2016. Findings revealed a positive adjustment on the CEO'S pay with an average of 3.325 thus implying to 6-10\% increment in CEO'S compensation.

\section{Organizational Performance (OP)}

Organizational performance was the study's independent variable. To determine the relationship between organizational performance and the other study variables, it was important to seek the Respondent's opinion on the extent to which they would consider it in determining the CEO'S performance and as such the level of compensation offered to the CEO. Organizational performance was measured using a 5 point Likert scale where the rating of 1 indicated very large extent to 5 representing not at all. Therefore a score of $\leq 1.5$ was interpreted to mean considered to a very large extent, while scores of 1.5 to $\leq 2.5$ indicated that the respondents considered the item to a large extent and 2.5 to $\leq 3.5$ was interpreted to mean that the respondents moderately considered the item. As for the mean scores a mean of 3.5 to $\leq 4.5$ was interpreted to mean that the respondent considered the variable to a less extent, while a mean score of $\geq 4.5$ was interpreted to mean the variable was not considered at all. In terms of the standard deviation, a value of $\leq 1$ was interpreted to mean that the Respondents agreed in the rating of the statement while a value of $>1$ was interpreted to mean Respondents differed in their opinion about the statement. 18 items were used to measure organizational performance in the listed firms. These items were adopted from the balanced score card as used by Kaplan and Norton (1996) that measures organizational performance in 4 dimensions of financial indicators, management of customer relations and growth, internal processes and learning and growth. The Respondent's opinion relating to the variable under each of the 4 dimensions of organizational performance is presented in the following sub-sections.

\section{Test of Hypothesis}

The study's objective aimed at establishing the influence of firm size on the relationship between organizational performance and CEO'S compensation. This was assessed by testing; Hypothesis: Firm Size

Moderates the Relationship between Organizational Performance and CEO'S Compensation. The hypothesis was tested using Baron and Kenny three step procedure for testing moderation.

Step 1: CEO'S compensation was regressed on organizational performance. Step 2: Firm size is added to the model. Step 3: The interaction between organizational performance and firm size was added to the 
regression model comprising organizational performance and firm size. The results of the tests are presented in table 2.

Table 2: Stepwise Regression Results for the test of Moderating Effect of Firm Size (FS) on the Relationship between Organizational Performance and CEO'S Compensation

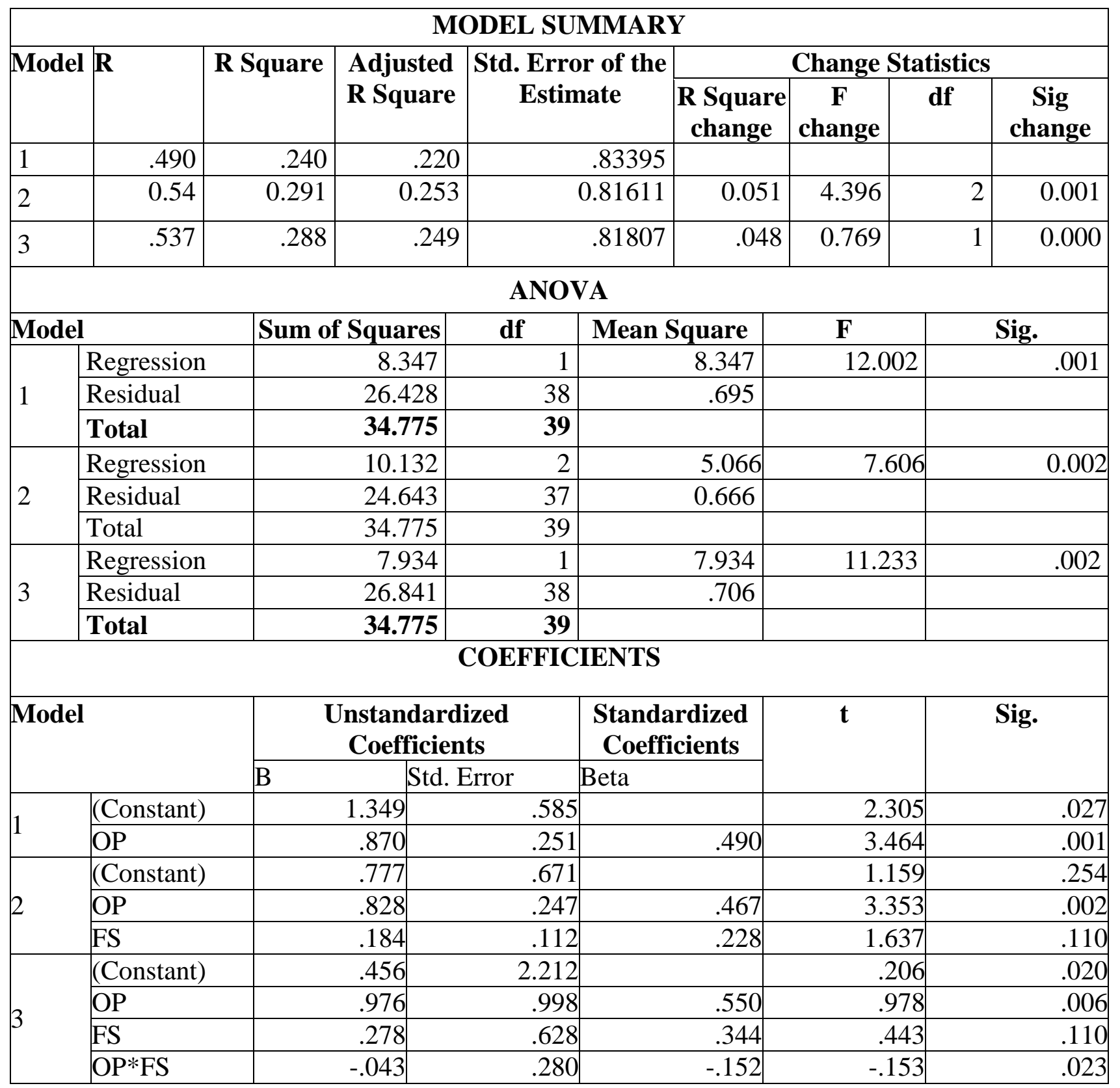

a. Predictors: (Constant), Organizational Performance

b. Predictors: (Constant), Firm Size

c. Predictors: (Constant), Organizational Performance, Firm Size

d. Dependent Variable: CEO'S Compensation

\section{Where;}

OP is Organizational Performance

FS is Firm Size

$\mathrm{OP} * \mathrm{FS}$ is the interaction term for organizational performance and firm size

In step one; CEO'S compensation was regressed on organizational performance. The findings presented in table 2 reveal that organizational performance had a significant effect on CEO'S compensation $\left(\mathrm{R}^{2}=0.24\right.$, 
$\mathrm{F}=12.002, \mathrm{P}<0.05$ ), and also implies model fit. The results indicate that $24 \%$ of variation in CEO'S compensation is attributed to organizational performance. The results also indicate a significant $\mathrm{F}$ ratio is an indication of model fit. The findings further revealed that a unit change in organizational performance is associated with $49 \%$ change in CEO'S compensation $(\beta=0.49, \mathrm{t}=3.464, \mathrm{P}<0.05)$.

In the second step; CEO'S compensation was regressed on both organizational performance and firm size. The findings presented in the table reveal a significant effect of firm size on CEO'S compensation $\left(\mathrm{R}^{2}=0.291, \mathrm{~F}=7.606, \mathrm{P}<0.05\right)$, implying that $29.1 \%$ of change in CEO'S compensation is attributed to organizational performance and a 5.1\% change in CEO'S compensation is due to firm size. The results also indicated a statistically insignificant relationship between the two variables $(\beta=0.228, \mathrm{t}=1.637, \mathrm{P}>0.01)$ suggesting that adding firm size to the model enhances the influence of organizational performance on CEO's compensation by 1 unit. This is because the individual effect of Firm size on CEO's compensation was positive.

In step three; an interaction of firm size and organizational performance was added in the regression equation. The purpose of adding the interaction term was to establish whether the moderator had significant effect on the relationship between organizational performance and CEO'S compensation. The findings in table 2 indicate a model fit $(\mathrm{F}=0.769, \mathrm{P}<0.01)$. The results further indicate a significant coefficient of determination in step three of the stepwise regression analysis $\left(\mathrm{R}^{2}=0.048,(\mathrm{~F}=0.769, \mathrm{P}<0.01)\right.$, suggesting that firm size explains $4.8 \%$ of change in CEO'S compensation. Further the influence of the interaction term between organizational performance and firm size on CEO'S compensation is at the rate of a unit increase in the interaction term (organizational performance*firm size to a decrease of -0.153 in CEO'S compensation $(\beta=-0.152, \mathrm{t}=-0.153, \mathrm{P}<0.05)$. The results therefore support the hypothesis which states that the effect of organizational performance on CEO'S compensation is moderated by firm size. In other words, firm size strengthens the relationship between organizational performance and CEO'S compensation. Thus the bigger the firm size the stronger the relationship between organizational performance and CEO'S compensation. From the findings the overall predictor model can be stated as: $\mathbf{C C}=\mathbf{0 . 4 5 6}+\mathbf{0 . 9 7 6 O P}+\mathbf{0 . 2 7 8 F S}-\mathbf{0 . 0 4 3 0 P} * \mathbf{F S}$ $+\varepsilon$

\section{Discussion of the findings}

The objective of this study was to establish the effect of firm size on the relationship between organizational performance and CEO's compensation. Stepwise regression analysis was used to test the hypothesis drawn from the objective. The results revealed a significant coefficient of determination in step three of the stepwise regression analysis $\left(\mathrm{R}^{2}=0.048,(\mathrm{~F}=0.769, \mathrm{P}<0.01)\right.$, suggesting that firm size explains $4.8 \%$ of change in CEO'S compensation. Further the influence of the interaction term between organizational performance and firm size on CEO'S compensation is at the rate of a unit increase in the interaction term (organizational performance*firm size to a decrease of -0.153 in CEO'S compensation $(\beta=-0.152, t=-0.153$, $\mathrm{P}<0.05)$. This implies that firm size enhances the relationship between organizational performance and CEO'S compensation $\left(\mathrm{R}^{2}\right.$ changed from 0.24 to 0.288 ). This could be explained as suggested by previous studies that increase in CEO'S compensation in large firms is justified by greater responsibility of the CEO, larger scale of operations and greater complexity in the CEO'S work (Hijazi and Bhatti, 2007). Sonenshine et. al. (2016) notes that previous research have empirically established that firm size play a key role in the determination of CEO'S compensation, and in line with this argument, CEO'S of larger firms receive higher compensation. The school of thought that believes in pay for performance, tends to argue that larger firms will attract highly competent CEO'S and amplifies CEO'S productivity by arguing that increases in firm size will upscale the resources under the CEO'S control and demands stronger incentives so as to keep the CEO'S interest aligned to organizational goals. The findings of this study are in line with this school of thought. As noted by Core et. al. (1999) CEO'S compensation can be seen as a function of firm performance, operational complexity, growth opportunities and board composition. However, there are no previous studies that examine the moderating effect of firm size on the relationship between organizational performance and CEO'S compensation. Instead, past studies only examine direct relationships between organizational performance and firm size on CEO'S compensation.

\section{Conclusion}

The purpose of this study was to investigate the influence of firm size on the relationship between organizational performance and CEO'S compensation for firms listed at the NSE. The objective of the 
study was met by confirming that firm size had a moderating positive and significant effect on the relationship between organizational performance and CEO'S compensation. The results indicated that the introduction of the interaction term (OP*FS) strengthened the relationship between the CEO'S compensation and organizational performance variable by explaining $28.8 \%$ of variation in CEO'S compensation, $\left(\mathrm{R}^{2}=0.288\right)$. The initial model of the relationship between organizational performance and CEO'S compensation revealed that organizational performance explained $24 \%$ of variations in CEO'S compensation where $\mathrm{R}^{2}=0.24$.

\section{Suggestions for further research}

This study only captured data for 40 firms listed at the NSE that had a total of 60 firms at the time the study was conducted. Future researchers may consider expanding the sample size of the study to include all the firms listed at NSE to increase generalizability of results across the firms. CEO'S compensation raise was measured using percentage increase of compensation from one year to another. However future researcher could use the actual figures of CEO'S compensation increase to be more precise if the information is accessible.

\section{References}

[1] Abed, S. Suwaidan, M. \& Slimani, S. (2014). The determinants of Chief Executive Officer Compensation in Jordanian Industrial Corporations, International Journal of Economics and Finance; Vol. 6, pp 110-118

[2] Aduda, J. (2011). The Relationship between Executive Compensation and Firm Performance in the Kenyan Banking Sector, Journal of Accounting and Taxation, Vol. 3(6), 130-139

[3] Alchian, A. \& Demsetz, H. (1972). Production, information costs, and economic organization. American Economic Review, 62: 777-795

[4] Baiman, S. and Verrecchia R. (1995). 'Earnings and price-based compensation contracts in the presence of discretionary trading and incomplete contracting', Journal of Accounting and Economics, Vol. 20:1, pp. 93-121

[5] Baker, G. P. \& Hall, B.J. (2004). CEO incentives and Firm Size, Journal of Labour Economics, Vol. 22, pp 767-798

[6] Baptista, M. (2010). CEO Compensation and Firm Performance in France. HEC, Paris Thesis

[7] Barney, J. B. (2002). Gaining and sustaining competitive advantage (2 ${ }^{\text {nd }}$ ed.) Upper Saddle River, NJ: Pearson Education, Inc.

[8] Bebchuk, L.A., \& Fried, J.M. (2004). Pay without performance. The unfulfilled promise of Executive Compensation, Cambridge, M.A. Harvard University Press

[9] Beer, M. (1969). Organizational size and job satisfaction, The Academy of Management Journal, Vol 7, pp 34-44

[10] Berle, A.A. \& Means, G.C. (1932). The Modern Corporation and Private Property, New York Macmillan

[11] Bernardin, J. (2007). Human Resource Management, an Experiential Approach, 3rd Ed, Tata McGraw-Hill Publishing Co., New Delhi.

[12] Bertrand, M. \& Mullainathan, S. (2001). Are CEO's rewarded for luck? The ones without principals are. Quarterly Journal of Economics, Vol. 116, pp 901-932

[13] Boyd, B. K. (1994). 'Board Control and CEO Compensation.' Strategic Management Journal, Vol. 15, No. 5. Pp. 335-344.

[14] Brick, I. E., Oded, P. \& Wald, J. (2005). CEO Compensation, Director Compensation and Firm Performance, Journal of Corporate Finance Vol. 12, pg. 112-118

[15] Brown, J., \& Fraser, M. (2006). Approaches and perspective in social and Environmental Accounting; An overview of the conceptual landscape, Business Strategy and Environment. Vol: 15: 103-117

[16] Buigut, K., Soi, N. \& Koskei, I. (2014). Determinants of CEO Compensation Evidence from UK Public Limited Companies, International Journal of Business and Management, Vol. 10, No. 1; 2015

[17] Chalmers, K., Koh, P.S., Stapledon, G. (2006). 'The determinants of CEO compensation. Rent extraction or labor demand?' The British Accounting Review 38, 259-275

[18] Chung, Y. (2010. CEO Ability, Pay, and Firm Performance. JEL Classification: G34, J24,J33 
[19] Cooper, D. R. \& Schindler, P.S. (2008). Business Research Methods, $10^{\text {th }}$ Edition, McGRAW-Hill.

[20] Core, J., Guay, W. \& Larcker, D. (2003). Executive Equity Compensation and Incetives: A Survey. FRBNY Economic Policy Review, 9, 27-50.

[21] Cyert, R., Sok-Hyon, K. \& Praveen, K. (2002). Corporate Governance, Take-overs, and TopManagement Compensation: Theory and Evidence. Management Science. 48:4, pp.. 453-69.

[22] Deckop, J. R. (1988). 'Determinants of Chief Executive Officer Compensation.' Industrial and Labor Relations Review, Vol. 41, pp. 215-226.

[23] Elhagrasey, G., Harrison, R. and Buchholz R. (1999). Power and Pay. The politics of CEO compensation, Journal of Management and Governance. Vol. 3: 213-251

[24] Eisenhardt, K., (1989). Agency Theory. An Assessment and Review, Academy of Management Review, Vol. 14: 57-74

[25] Epstein,M and Roy,M. (2002). Measuring and improving the Performance of Corporate Board. The Society of Management Accountants of Canada, Hamilton

[26] Farmer, M. (2008). Chief Executive Compensation and Company Performance: a weak relationship or measurement weaknesses? Kingston University, UK

[27] Finkelstein, S. \& Hambrick D.C., (1989). Chief Executive Compensation: a study of the intersection of markets and political processes, Strategic Management Journal Vol. 10.

[28] Fleming, G., \& Stellios, G. (2002). CEO compensation, Managerial Agency and boards of directors in Australia. Accounting Research Journal, 15(2), 126-145.

[29] Frydman C. and Jenter D. (2015). CEO Compensation, working paper. Stanford University

[30] Gabaix, X., Landier, A. \& Sauvagnat, J. (2013). CEO pay and firm size: an update after the crisis, Journal of business economics \& statistics Vol. 31, pp 44-79.

[31] Gabaix, X. \& Landier, A. (2008). Why has CEO pay increased so much? Quarterly Journal of Economics, Vol. 123, pp 49-100

[32] Gayle, G. and Miller, R. (2009) Has Moral Hazard Become a More Important Factor in Managerial Compensation? American Economic Review, 99, 1740-1769.

[33] Guest, M.P. (2009). Board Structure and Executive Pay: evidence from the UK. Cambridge Journal of Economics, vol31.

[34] Gunasekargea, A., and Wilkinson, M. (2002). CEO Compensation and firm performance: A New Zealand investigation. International Journal of Business Studies, 10(2), 45.

[35] Healy, P. (1985). The effect of bonus schemes on accounting decisions, Jounal of Accounting and Economics, Vol. 7, pp. 85-107

[36] Hermalin, B.E. (2005). Trends in Corporate Governance, Journal of Finance, vol. 60(5), pp. 23512384

[37] Hijazi, S. T. \& Bhatti, K. K., (2007). 'Determinants of Executive Compensation and its Impacts on Organizational Performance.' Compensation \& Benefits Review, Vol. 39., No. 2, 58-68

[38] Himmerlberg, C.P. \& Hubbard, R.G. (2000). Incentive pay and the market for CEO's. An analysis of pay-for performance sensitivity, Working paper, Columbia university

[39] Holmstom, B. \& Kaplan S. (2003). The state of US Corporate governance: What's right and what's wrong? Journal of Applied Corporate Finance, Spring:8-20

[40] Izan, H. Y., Sidhu, B. \& Taylor, S. (1998). Does CEO pay reflect performance? Corporate Governance: an International Review, 6, 39-47

[41] Jensen, M. C. \& Murphy, K .J. (1990). Performance Pay and top management incentives; Journal of Political Economy, Vol. 98

[42] Jensen, M.C. and Meckling, W.M. (1976). The theory of the firm: Managerial behavior, agency costs and ownership structure. Journal if Financial Economics, 3, 305-360.

[43] Jones, D. C., Kato, T. (1996). 'The determinants of chief executive compensation in transitional economies,' Evidence from Bulgaria.' Labor Economics. 3, 319-336.

[44] Kaplan, R.S. and Norton, D.P.(2000). The Strategy-focused organization: How balanced scorecard companies thrive in the new business environment, Harvard business school press, Cambridge.

[45] Kaplan, R.S. and Norton, D.P.(1996). The Balanced Scorecard, Havard Business School Press, Cambrdge, M A.

[46] Kerr, J. and Bettis, R. A. (1987). Boards of Directors, top management compensation and shareholder returns, Academy of Management Journal, Vol 30: 645-664 
[47] Khanna, V. (2016). Determinants of CEO Compensation, International Journal of Management Excellence, 6(2)

[48] Kimberly, J.R. (1976), Organizational size and structuralist perspective: A review, critigue and proposal, Administrative science quarterly, 21(4) 571-597

[49] Kubo, K. (2001). The Determinants of Executive Compensation in Japan and the UK. Working paper series, No. 2001-2, Institute of Economic Research Hitotsubashi University.

[50] Lambert, R. A., Larcker, D. F., and Weigelt, K. (1991). 'How Sensitive is Executive Compensation to Organizational Size?' Strategic Management Journal, Vol. 12, pp. 395-402.

[51] Leonard, J. (1990). Executive pay and Firm Performance, Industrial and labour relations review, Vo. 43, pp 13-29

[52] Magnan, M. L., St-Onge, Thorne, L. (1995). 'A comparative analysis of determinants of CEO compensation between Canadian and U.S firms. Industrial Relations Vol. 50, 297-319.

[53] Main, G. M., O'Reilly, C. A. and Wade, J. B. (1995). 'The CEO, the board of directors and executive compensation: economic and psychological perspectives', Industrial and Corporate Change, Vol. 4 pp293-332

[54] McGuire J. W., Chiu J. S., Elbing A. O. (1962). 'Executive Incomes, Sales and Profits.' The American Economic Review, Vol. 52, pp. 753-761.

[55] Malkzadeh, A. (2002). Implications of CEO structural and ownership powers, board ownership and composition on the market's reaction to Antitakeover Charter Amendments. Journal of Applied Business Research, Vol. 14, No. 3: 53-62

[56] Morck, R., Shleifer, A., Vishny R.W. (1990). Do Managerial objectives drive bad acquisitions? Journal of Finance, Vol. 45, pp 31-48

[57] Ongore, V. (2008). The Effect of Ownership Structure Board Effectiveness and Managerial Discretion on Performance of listed Companies in Kenya, unpublished PhD Thesis, UoN.

[58] Ozkan, N. (2011). CEO Compensation and Firm Performance: an Empirical Investigation of UK Panel Data, European Financial Management, Vo. 17, pp 260-285

[59] Owen D. (2006). Emerging issues in sustainability reporting, Journal Business Strategy and the environment, Vol. 15: pp217-218

[60] Parthasarathy, A., Menon, K. \& Bhattacherjee, D. (2006), Executive Compensation, Firm Performance and Governance, Economic and Political Weekly

[61] Penrose, E.T., (1995). The theory of the growth of the firm, New York: Wiley

[62] Porter, M. (1980). Competitive Strategy, Free Press, New York

[63] Post J. (2002). Redefining the corporation: Stakeholder management and original wealth, Stanford University press, Palo Alto

[64] Ramaswamy, (2000). A study of the Determinants of CEO compensation in India. MIR Management International Review, 40(2), 167.

[65] Reed, R., Lemak, D.J. \& Mero, N.P. (2000). Total quality management and sustainable competitive advantage. Journal of Quality Management, Vol. 5 No. 1, 5-26.

[66] Reich R. (1998). The new meaning of corporate social responsibility, Asian Business and Management, Vol 4: pg. 95-115

[67] Roberts, D. (1959). 'A General Theory of Executive Compensational Performance: A longitudinal analysis. Strategic Management Journal, 12(2): 155-160.

[68] Rose, N. and Joskow, P. (1994). CEO pay and firm performance: Dynamics, asymmetries, and Alternative performance measures. Journal of Financial Economics, 3(4), 305-360

[69] Rosen, S. (1982). Authority Control and distribution of earnings. Journal of Economics, Vol. 13, pp. 311-323

[70] Sapp, S. G. (2007). The impact of Corporate Governance on Executive Compensation.

[71] Shah, S. Z., Javed, T. \& Abbas M. (2009). Determinants of CEO compensation, Emperical Evidence from Pakistani Listed Companies, International Research Journal of Finance and Economics

[72] Sigler, K.J. (2011). CEO Compensation and Company Performance. Business and Economics Journal, Volume 31.

[73] Simon, H. A. (1957). Compensation of Executives. Sociometry 20: 32-35.

[74] Sonenshine, R., Larson, N. and Cauvel, M. (2016) Determinants of CEO Compensation before and after the Financial Crisis, Modern Economy, 7,1455-1477. 
[75] Tarus, K. E., Basweti, A. K. and Nyaoga, B. R. (2014). The Relationship between Executive Compensation and Financial Performance of Insurance companies in Kenya, Research Journal on Finance and Accounting, Vol. 5 (1), 113-122

[76] Tervion, M. (2008). The difference that CEO's make: an assignment model approach, American Economic Review, Vol. 98, pp.642-668

[77] Trigueiros, D. (2000). A theoretical definition and statistical description of firm size, International Jjournal of Economics, Vol 6, pp 159-164

[78] Upadhaya, B., Munir, R., \& Blount, Y. (2014). Association between Performance Measurement Systems and Organizational Effectiveness. International Journal of Operations \& Production Management, 34(7), 2-2.

[79] Wade, J. B., Porac, J. F. \& Pollock, T. G. (1997). Worth, Words and the Justification of Executive Pay, Journal of Organizational Behaviour, Vol. 18, John, W. and sons. 